\title{
Estimating the Impact of Credit Risk Determinants in two Southeast European Countries: A Non-Linear Structural VAR Approach
}

\author{
MICHAIL KAROGLOU \\ Aston Business School, Economics and Strategy Group \\ KOSTAS MOURATIDIS* \\ University of Sheffield \\ SOFOKLIS VOGIAZAS \\ Black Sea Trade and Development Bank
}

\begin{abstract}
We study the impact of credit risk determinants on the Romanian and Bulgarian banking systems using a structural Markov Regime-Switching vector autoregressive (MRSSVAR) analysis. To capture changes in the domestic macroeconomic conditions as well as the spillover effects from the Greek crisis we account for endogenous breaks in the mean and/or volatility dynamics. Our empirical results suggest that an increase of interest rate also increases the Romanian and Bulgarian credit risk in the short-run while in the medium and long-run it reduces it. We also find evidence of spillover effects from the Greek crisis on both the Romanian and Bulgarian banking system which, interestingly, are imminent in the low volatility regime.
\end{abstract}

Keywords: credit risk, structural VAR, breaks, Markov Regime Switching

JEL codes: C32, E44, E51, G21

\section{Introduction}

The 2007/08 financial crisis and the ongoing sovereign debt crisis have inflicted a powerful blow to the framework within which central banks operate. In particular, before these crises, central banks were typically assigned to exploit the monetary transmission mechanism in order to achieve price stability without destabilizing economic growth. In this spirit, many of them were made independent and in turn adopted credible policy rules. Nowadays, however, it has

\footnotetext{
* Corresponding author; University of Sheffield, Department of Economics, 9 Mappin Street, Sheffield, S1 4DT. Email: k.mouratidis@sheffield.ac.uk

(C) 2017 Michail Karoglou, Kostas Mouratidis and Sofoklis Vogiazas. Licensed under the Creative Commons Attribution - Noncommercial 3.0 Licence (http://creativecommons.org /licenses/by-nc/3.0/). Available at http://rofea.org.
} 
become clear that the monetary transmission mechanism is a substantially more complex process. Angeloni et al. (2010) for example shows that if monetary policy contributes to the formation of financial risk, and if in turn, financial risk feeds back on macroeconomic variables with unknown lags, then monetary policy has to take into account its possible impact on financial stability. Consequently, it appears that a proper understanding of the linkages between financial risk, monetary policy, and the business cycle is key in determining monetary policy.

In this paper, we examine the factors affecting the credit risk of two South East European (SEE) countries namely Romania and Bulgaria. Estimating the impact of macroeconomic and financial variables on the credit risk of these countries is important for at least three reasons. First of all, after the financial crisis in the second half of the 90s, most SEE countries enjoyed a rapid economic growth which was funded by mobilizing deposit and capital inflows. However, the relevant empirical literature has shown that rapid credit growth may well trigger banking crises through macroeconomic imbalances and the inevitable deterioration of loan quality. ${ }^{1}$ Since (a) the financial deepening in Bulgaria and Romanian is lower compared to other countries that joint the EU in $2004 ;^{2}$ and (b) the average annual credit growth rate over the euphoria period of 2005-2007 in both countries have reached considerably higher levels than any other country in the region, it is reasonable to expect that these two economies are much more likely to experience some form of financial crisis, at least when compared to other accession countries.

Second, given that Romania and Bulgaria have gone through a process of financial deepening and transformation from a planned to a market economy, their banking systems did not have the chance to test their resilience over the full economic cycle. This adds an additional element of uncertainty about the factors and the extent to which each of them determines the credit risk.

Finally, the Romanian and Bulgarian banking sectors are dominated by foreign banks among them the Greek banks form a critical base in terms of capital invested and financial assets. ${ }^{3}$ The significant presence of Greek banks exposed the Romanian and Bulgarian banking

${ }^{1}$ For instance, Duenwald et. al (2005) argue that given short-run supply constrains credit expansion can generate current account and fiscal deficits. A sudden reversal of capital inflows as well as of policy responses could lead to a hard landing for the economy, as manifested by higher interest rate, a decrease of economic growth, of assets prices and pressures on exchange rate. Furthermore, depending on the sector' exposure to those risks, high interest rate, low economic growth and exchange rate pressures may exert a banking sector distress.

${ }^{2}$ For instance, in 2008 the share of Banks' total assets as a percentage of GDP was 80 per cent in Bulgaria and Romania in comparison to 262.3 in the Euro area and 100 percent in five new central and East European member states (Hungary, the Czech Republic, Poland, Slovakia and Slovenia).

${ }^{3}$ Greek banks accounted for $22.9 \%$ of the total foreign capital injected in the Romanian banking system holding about $14 \%$ and $12 \%$ of system's assets and deposits respectively (NBR, 2012; IMF, 2012). Alternatively, Greek banks account for the $25 \%$ of total credit volume of the Bulgarian banking system. 


\section{KAROGLOU Impact of Credit Risk Determinants}

system to materialized risk manifested in a steady rise of non-performing loans (IMF, 2012). The legacy of consumption and credit boom during the 2000s exposed the banking sector to uncertainty arising from the global financial turbulence and spillovers from the Greek debt crisis due to the strong economic and financial links between the two SEE countries and Greece. Evidence of spillover effects from the Greek twin (debt-banking) crises has important implications not only for the financial stability of SEE countries but indirectly for the euro-area as these countries will shortly adopt the single currency. ${ }^{4}$ If there is evidence of spillover effects from the Greek banking system to the Bulgarian and Romanian banking systems then the adoption of a single currency by these countries has to be designed by accounting not only for macroeconomic factors of the domestic economies but also macro-economic variables that relate them to the Greek economy.

This paper aims to contribute to the empirical literature on the relationship between macroeconomic conditions and banks' credit risk. Empirical studies are constrained either by small samples or incomplete data. For instance, most studies use series up to 2007-2008 because empirical evidence suggests that the statistical properties of data during crisis differ from those in stable times (Danielsson, 2002; Haldane, 2009a). ${ }^{5}$ Applied researchers avoid the issues that structural breaks give rise to by focusing on sub-samples which they assume homogenous i.e. as having the same data generating process. However, for models that are built upon forwardlooking agents the formation of expectations should in principle account for possible parameter changes in the future. While in a stable period the formation of expectations is an endogenous linear process, in a sample with regime switches, structural breaks, or other latent dynamics this process is by default a non-linear endogenous or exogenous stochastic process. ${ }^{6}$

Unlike the existing literature, we account for structural breaks by assuming that breaks are endogenous. In particular, we employ a Markov regime-switching structural vector autoregressive (MRS-SVAR) specification. Furthermore, and in line with Canova and De

\footnotetext{
${ }^{4}$ The Greek debt crises manifested also as a banking crisis by infusing a lack of confidence about the ability of Europe to handle banking crises in other member countries such as Spain and Ireland. As the Greek crisis escalated, the term "Grexit" was added to the financial vocabulary. During this period the Greek spread raised to a historical level leading to contagion in the Eurozone's other peripheral countries. Greece was bailed-out twice while Ireland and Portugal were bailed out for $£ 85$ and $£ 78$ bn respectively. Spain was also granted, in July 2012, financial assistance from the European Stability Mechanism for up to $£ 100 \mathrm{bn}$. Despite these bailouts, international financial markets still remain unconvinced about the sustainability of the debt level in the aforementioned.

${ }^{5}$ This explain why the results of recent macro-stress tests had been criticized for depicting an either too rosy or too bleak picture of banking system vulnerabilities (Sorge, 2004; Haldane, 2009a; Alfaro and Drehmann, 2009).

${ }^{6}$ For example, structural breaks might be the outcome of endogenous regime change concerning the framework of monetary and/or fiscal policy. Alternatively, a structural break might be driven by aggregate shocks unrelated to the pre-shock structural economic model, which generated the data.
} 
Nicoló (2002) who show that in SVAR analysis the conventional identification strategies based on zero restrictions may well end up inconsistent with their underlying theoretical models, we identify the structural relationships by imposing model consistent sign restrictions on the impulse responses of credit risk to a set of macroeconomic and bank-related shocks. Finally, we investigate the existence of spillover effects to the Bulgarian and Romanian banking system from Greece, an economy that is particularly relevant in the current period not least because of its crisis that ensued in the aftermath of the 2007/8 financial crisis and marked the beginning of the ongoing sovereign debt crisis.

Overall, our empirical results suggest that credit growth and unemployment have a positive impact on both Romanian and Bulgarian credit risk while money supply has a negative impact. ${ }^{7}$ Note that the opposite effects of monetary policy and of credit expansion on credit risk emphasize the role of the risk-taking channel in the monetary transmission mechanism. In particular, the risk-taking channel underlies the link between monetary policy and the perception of risk by economic agents. In effect, it implies that the financial system facilitates investment managers to assume more risk in a low-interest rate environment and dovish monetary policy because portfolio managers compensated on the basis of nominal interest rate have an incentive to search for higher yield risky projects. Our results also suggest the presence of spillover effects from the Greek crisis at least to the Romanian banking system. ${ }^{8}$

The remainder of the paper is as follows. Section 2 reviews the literature on the linkages between macroeconomic conditions and banks' loan quality. Section 3 describes the data and Section 4 the econometric methodology we adopt. Section 5 presents and discusses the results. Finally, Section 6 summarizes and concludes.

\section{Theoretical Underpinnings and Empirical Literature}

Our study is directly relevant to the theoretical contributions and empirical investigations strands of literature that examine the links between macroeconomic and financial variables with credit risk. Consequently, the first part of this section explains how macroeconomic shocks can

\footnotetext{
${ }^{7}$ The results confirm and expand studies on the Romanian banking systems credit risk (IMF, 2010; Klein, 2013; Nikolaidou and Vogiazas 2011).

${ }^{8}$ This result is not consistent with of Nikolaidou and Vogiazas (2014) who show that the Greek debt crisis appeared to play an immaterial role indicating that Greek banks have not been a Trojan horse in the Bulgarian banking system might help the authors reconcile some of their own findings. Note that the approach followed by Nikolaidou and Vogiazas (2014) was mainly focused on the long-run relationship between credit risk and macro-variables. In our case we focus on the short-run using impulse response function analysis which has not been addressed by Nikolaidou and Vogiazas (2014). Furthermore, we have accounted for regimes changes by treating regime shifts as endogenous in line with some theoretical model of currency crises.
} 


\section{KAROGLOU Impact of Credit Risk Determinants}

be transmitted to the banking sector while the second part provides a review of the recent empirical findings.

\subsection{Recent Theoretical Developments}

The financial accelerator mechanism seems to be the principal notion around which revolve the most recent theoretical underpinnings about the links between macroeconomic and financial variables with credit risk, and Bernanke et al. (1999) provide a fitting setup. They combine nominal rigidities with agency costs to investigate the interaction between credit market factors and price stickiness. They conclude that the presence of credit market frictions gives rise to the financial accelerator mechanism that affects output dynamics. In turn, the financial accelerator mechanism has also important implications about the impact of monetary policy on output fluctuations and on credit risk. In particular, the presence of nominal rigidities gives the central bank some control over the short-term real interest rate. However, monetary policy affects output dynamics not only through the conventional channel, through which the interest rate affects aggregate spending but also through the impact of interest rate on borrower's balance sheet. For example, a reduction of real interest rate has a positive impact on assets prices, improving borrowers' net worth and reducing the external finance premium. The reduction of premium in turn provides an extra stimulus for investments.

However, a lower interest rate does not only increase the borrowing capacity of high-risk firms but also encourages portfolio managers who are compensated on the basis of nominal returns to engage in riskier, high-yield projects. This channel is known as the risk-taking channel. It implies that the direction of causality runs from monetary policy to credit risk because monetary policy has financial stability implications by affecting the incentives of banks managers (Borio and Zhu, 2008).

Although the original financial accelerator model did not incorporate banks, recent dynamic stochastic general equilibrium (DSGE) models explicitly incorporate banks so as to analyze the interaction between credit risk and macroeconomic variables. In these models, the impact of monetary policy on credit risk is not clear-cut despite the fact that its impact on bank lending is set explicitly positive.

For instance, Angeloni and Faia (2009) and Angeloni et al. (2010) ${ }^{9}$ argue that a lower interest rate following an expansionary monetary policy shock reduces banks' funding cost and increases the probability to repay depositors. Banks maximize profits by choosing optimally to increase leverage. However, in a low-interest rate environment bank returns on assets decline

\footnotetext{
${ }^{9}$ See also Allen and Gale (2000) for a more elaborate theoretical treatment.
} 
and an increase in leverage increases credit risk. Thus, an expansionary monetary policy shock has a positive impact on credit risk. ${ }^{10}$

In the same spirit, Zhang (2009) shows that expansionary monetary policy shock or technological shock has a negative impact on credit risk. In this setup, loan contracts between banks and firms are based on the expected future capital returns and the expected default rates. It is therefore argued that banks and firms share macroeconomic risk because banks cannot underwrite a loan contract by ignoring macroeconomic risk (Zhang, 2009). Thus, a positive technological shock increases the capital returns above their expected levels, which in turn lead to lower than expected by banks default rate. Consequently, banks realize unexpected profits, which enhance banks' balance sheet position and therefore reduce the probability of default. Meh and Moran (2010) reach the same conclusion in a model with a double moral hazard problem between banks and depositors and between banks and firms.

\subsection{A Brief Review of Empirical Studies}

There are a plethora of papers that have attempted to shed light on various aspects of this topic, which is also indicatory of the significance that the academic community has paid and continues to pay to it. In this section, we endeavor to give the reader a flavor of the recent developments in the field.

Reinhart and Rogoff (2008) have stressed that financial crises tend to be preceded by a recurrent set of economic developments. For instance, Alessi and Detken (2008) and Goodhart and Hoffman (2008) found that monetary and credit aggregates can be used as leading indicators for asset price boom/bust cycles respectively. However, this does not necessarily establish a causal relationship between monetary policy and credit risk although it does suggest that variables, which are under the control of monetary policy, should be monitored closely.

Duenwald et al. (2005) show that rapid credit growth triggers distress in the banking sector through the channels of macroeconomic imbalances and asset quality deterioration. This is also evident both in the Romanian and Bulgarian banking system (see Cottarelli et al, 2005; Duenwald et al, 2005). However, the loan quality is not only susceptible to macroeconomic shocks but also to banks' excessive risk-taking. Gavin and Hausmann (1996) note that excessive credit growth gives rise to banking crises as it usually goes hand-in-hand with a decline in credit standards. In a similar spirit, Hardy and Pazarbasioglu (1998) show that credit expansion to the private sector, associated with rising consumption and real interest rates, typically precedes banking crises.

\footnotetext{
${ }^{10}$ A similar mechanism increases the credit risk after a positive technological shock. This is because a positive technological shock reduces inflation and interest rate, and increases output.
} 


\section{KAROGLOU Impact of Credit Risk Determinants}

A number of papers such as Rajan (2005) and Borio and Zhu (2008) analyze the risk-taking channel of monetary policy by investigating whether or not a low-interest rate encourages lending to high-risk projects. Empirical studies using bank-level data show that an expansionary monetary policy indeed increases banks' risk (see for instance Altunbas et al., 2009; Ioannidou et al., 2009 and Gambacorta, 2009). In the same vein, Eickemeier and Hofmann (2010) and Angeloni et al. (2010) based on time series evidence shows that a positive monetary policy shock leads to a decline in various credit spreads and to an increase in bank balance sheet risk. Also, De Graeve et al. (2008) using a model that captures the interaction between bank-level distress and macroeconomic risk found that the probability of distress declines after a positive monetary policy shock.

At this point, it is worth noting that a large number of empirical studies in this context implement VAR analysis. Therefore, it is not surprising that VAR models have been the main tools in stress-testing exercises that aim to estimate the impact of macroeconomic variables on credit risk.11 In this spirit, Hoggarth et al. (2005) estimate the connection between loan writeoffs and the output gap, retail prices, real estate prices, short-term interest rate and the real exchange rate for the case of the UK and found that real GDP and inflation have a significant impact on loan portfolio quality. Marcucci and Quagliariello (2008) analyze the cyclical behavior of default rates of Italian banks and find that default rates changes across the business cycle and in particular that they decline during expansions and increase during recessions. Alves (2005) and Shahnazarian and Asberg-Sommer (2009) build cointegrating VAR models using Moody's KMV expected default frequencies (EDF) to analyze the response of corporate sector EDFs to macroeconomic shocks. The former (Alves, 2005) shows that both systemic and macroeconomic factors affect the steady-state risk profile of most sectors while the latter (Shahnazarian and Asberg-Sommer, 2009) indicates that macroeconomic variables provide significant information in forecasting future EDF. In general, these studies show that there is an interaction between credit quality and macroeconomic environment.

Finally, it is worth mentioning the growing literature that looks at the linkages between nonperforming loans and macroeconomic conditions. For example, Bouvatier and Lepetit (2007) using a sample of 186 European banks over 1992-2004, show that loan loss provisions amplify credit fluctuations. Espinoza and Prasad (2010) using bank-level data for a sample of 80 banks of the Gulf Cooperation Council (GCC) region show that the non-performing loans (NPL) ratio increase as economic growth decelerates and interest rates increase. Nkusu (2011) using a panel

\footnotetext{
${ }^{11}$ For example Castrén, Dées and Zaher (2008) use a Global Vector Autoregressive (GVAR) model as a macro-econometric framework to generate shocks to the financial system. They show that at the euro area level, the median of EDFs reacts to shocks to GDP, exchange rate, equity prices and oil prices.
} 
Review of Economic Analysis 10 (2018) 55-74

VAR model on a sample of 26 advanced economies found that the confluence of adverse responses in key macroeconomic indicators such as GDP and unemployment leads to a downward spiral in which banking system distress and the deterioration in economic activity reinforce each other.

\section{Data}

Our monthly dataset consists of five variables ${ }^{12}$ for both Bulgaria and Romania spanning over the period 2001-2015. The testable hypothesis in our investigation relates to the impact of macroeconomic and bank-related factors on the credit risk of the Bulgarian and Romanian banking systems. In the case of Bulgaria, we proxy credit risk by the growth rate of the ratio of loss and doubtful loans to total loans (DNPL) while in the Romanian context we use the growth rate of the ratio of loan loss provision to total loans (DLLP). ${ }^{1314}$ In both countries, our dataset captures the macroeconomic - monetary conditions by the growth rate of industrial production index (DIP) while the monetary policy shock is approximated by the changes in the short-term interest rate (DIR). Among the bank-specific variables, we use the credit growth (DLLOAN) approximated by the differenced logarithm of gross loans to non-bank corporations and private individuals. The use of credit growth accounts for the dynamic and competitive nature of both banking systems in the pre-crisis period. Given that a substantial part of the Romanian and Bulgarian banking systems' assets was controlled by Greek banks, we use the Greek bank's credit risk to estimate the spillover effects from the Greek debt crisis and bank distress on the Bulgarian and Romanian banking system. We proxy the Greek banks' credit risk by using the growth rate of the ratio of loan provisions to total gross - domestic and foreign - loans (DLLPG). ${ }^{15}$

\footnotetext{
${ }^{12}$ This also allows us to keep the MRS model - see section 4- tractable given the notorious impact of dimensionality on such models.

${ }^{13}$ In accordance with the Bulgarian National Bank (BNB), doubtful loans include all past-due loans (90+ days) and those loans where the borrowers' financial profile has substantially deteriorated. Loss loans are defined as past-due loans in excess of 181 days and credit exposures where there are valid grounds to consider that borrowers are in permanent financial inability to repay.

${ }^{14}$ Typically, studies use non-performing loans, loan loss provisions or other composite indices to assess a banking system's vulnerability over time. Romanian data of non-performing loans were not available for the entire time-period of our research. More concretely, the Romanian authorities began reporting past-due loans, defined as loans past-due over 90 days, in 2004 while the IMF database reports Romanian non-performing loans from 2003 onwards. Therefore, the use of NPL in Romania was not possible due to data availability issues.

${ }^{15}$ The proxy is justified by the fact that a substantial part of both countries banking assets are owned by Greek banks.
} 


\section{KAROGLOU Impact of Credit Risk Determinants}

Our sample starts in January 2001 given that the Romanian authorities initiated the first bank privatizations in 1999 while the privatization of commercial banks in Bulgaria was virtually completed in 2001-2002 (Frommel and Karagyozova, 2008). Previously, the competition in both banking systems was distorted by state-owned banks. Thus, the active expansion of foreign banks in both countries took place around 2001 concurrently with the introduction of the euro and the sharp decline in interest rate margins in the foreign banks' homelands. The dataset and the sources can be viewed on Tables 1 in the Appendix.

\section{Methodology}

The existing empirical literature on the relationship between loan-portfolio quality and economic activity has mainly utilized linear models. Furthermore, most empirical studies use data up to recent 2007-08 financial crisis to avoid contaminating their results by the possible regime shifts. ${ }^{16}$ The remainder of this section explains how exactly our conduct deviates from this literature.

To account for the case of omitted or latent nonlinearities we allow the coefficients of a structural VAR model to change across different regimes. The rationale is articulately presented in Davig and Leeper (2007) and Cooley et al. (1982) and we refer the interested reader to these papers for more in-depth discussions of the topic. Here, we restrict ourselves to note simply that the aforementioned papers show that the theoretical norm, which follows Lucas (1976) in treating regime shifts as a one-off event rather than as an ongoing process, is logically inconsistent since agents form expectations which reflect the belief that a regime change is possible. We adopt a Markov Regime Switching (MRS) framework to account for endogenous regime changes.

The MRS approach allows for the data generating a process to exhibit completely different dynamics across a predefined number of regimes. The process can 'switch' from one regime to another several times yielding a stochastic behavior that resembles the presence of breaks which the relevant literature often calls endogenous to signify the fact that their appearance is modeled. The remainder of this section discusses in more detail the MRS model.

\subsection{Markov-switching Structural VAR (MRS SVAR)}

A MRS SVAR combines two important developments of VAR analysis: Markov regimeswitching and identification. We estimate a MRS VAR model, where we allow all estimated parameters to be state dependent:

\footnotetext{
${ }^{16}$ For example, Ang and Timmermann (2011) and Gordon (2012) suggest that substantial changes in the properties of time series are attributed to large-scale events, such as financial crises.
} 
Review of Economic Analysis 10 (2018) 55-74

$$
Y_{t}=\sum_{i=1}^{p} \Phi_{i}\left(s_{t}\right) Y_{t-i}+\mathcal{E}\left(s_{t}\right)
$$

where $s_{t} \in \Omega=\{1, \ldots n\}$ is the unobserved state variable which follows a Markov process with transition probability matrix $P=\left(p_{i j}\right)^{\mathrm{i}, \mathrm{i}, \mathrm{\epsilon} \Omega}$. The elements of transition probability matrix show that if the unobserved state variable at time $t$ is in regime $i$ there is a probability $p_{i j}$ to move on regime $j$ at $t+1$ (i.e. $p_{i j}=P\left(s_{t+1}=j \mid s_{t}=i\right)$ ).

We identify a state-dependent structural shock $u\left(s_{t}\right)=A\left(s_{t}\right) \varepsilon\left(s_{t}\right)$ by imposing sign restrictions on the impulse response of credit risk to a set of macroeconomic and banking specific shocks. Note that impulse responses are regime dependent and computed based on the QR decomposition of an $n \times n$ random matrix $K$ and the Cholesky factor of

$$
\Sigma_{\varepsilon}\left(s_{t}\right)=A\left(s_{t}\right) A\left(s_{t}\right)^{\prime}
$$

More concretely, we draw a $n \times n$ random matrix $K$ from a standard Normal distribution $N(0,1)$, then we take the $Q R$ decomposition of $K=Q R$ and compute the structural impact matrix as $A\left(s_{t}\right) *=A\left(s_{t}\right) Q^{\prime}$. If the draw satisfies the restriction we keep it otherwise we disregard it. ${ }^{17}$

To achieve identification of the VAR system, we impose a positive response of credit risk (DLLP) to positive shocks due to credit growth (DLLOAN), interest rate changes (DIR) and the Greek credit risk (DLLPG). Alternatively, we impose that the response of credit risk to output growth (DIP) is negative. At this point, it is worth underlying that the aforementioned approach allows for the data to speak. In other words, if the restriction is not valid then it will be rejected by the shape of the impulse-responses.

\section{Empirical Results}

This section presents and discusses our results. Overall, the inference we can draw from our results can be summarised into the three following points.

First, we observe that a monetary policy shock increases bank risk at the impact but after few periods following the shocks bank risk decline. This might be driven by the "flight to quality" argument of Bernanke et al. (1996). In particular, an increase of the interest rate will have a negative impact on firms and banks' balance-sheet. This will increase the interest rate burden for firms and thereby the probability of default. Also higher interest rate will increase agency cost and discourage banks to invest on high risk projects. Thus, we observed an initial increase of bank risk due to deterioration of balance-sheets and then a decline of bank risk due to flight to quality behaviour of banks.

\footnotetext{
${ }^{17} Q$ is a unitary matrix and $R$ is an upper triangular matrix.
} 
Second, we observed significant spillover effects from the Greek credit risk to Romanian and Bulgarian bank risk. Note however, that the impact of Greek credit risk on domestic bank system is positive and significant in the low volatility regime while becomes negative and even not significant in the high volatility regime. This might reflect the prudent behaviour of supervisory authorities of the respective SEE countries and the "Vienna" Initiative.

Finally, there is not any evidence that both credit growth and output growth have any significant impact on bank risk. This might be driven by the countervailing effect of both variables. In particular, while output growth might have a negative impact on bank risk credit growth will have a positive impact.

The remainder of this section present and discuss our more specific results for the Romanian and Bulgarian banking systems respectively.

\subsection{Results for the Romanian Banking System}

Figure 1 outlines our results for the determinants of the Romanian credit risk depicting the filter probability of regime 1 (at the top) and the responses of credit risk to a positive shock of the variables DLLOAN, DLLPG, DIR and DIP for regime 1 (left panel) and regime 2 (right panel).

We identify regime 1 as the low volatility regime and regime 2 as the high volatility regime. The timing of the switches as depicted in the filtered probabilities allows us to argue that the low volatility regime coincides with expansion while the high volatility regime coincides with the recession. The filter probability of regime 1 indicates that with short-periods of disruptions the low volatility regime is present with high probability up to the end 2008. After the 2007-08 financial crisis the high volatility regime (i.e. regime 2 ) becomes fixed with a high probability till the end of 2014 .

Figure 1: Filtered Probabilities for regime 1 for Romania

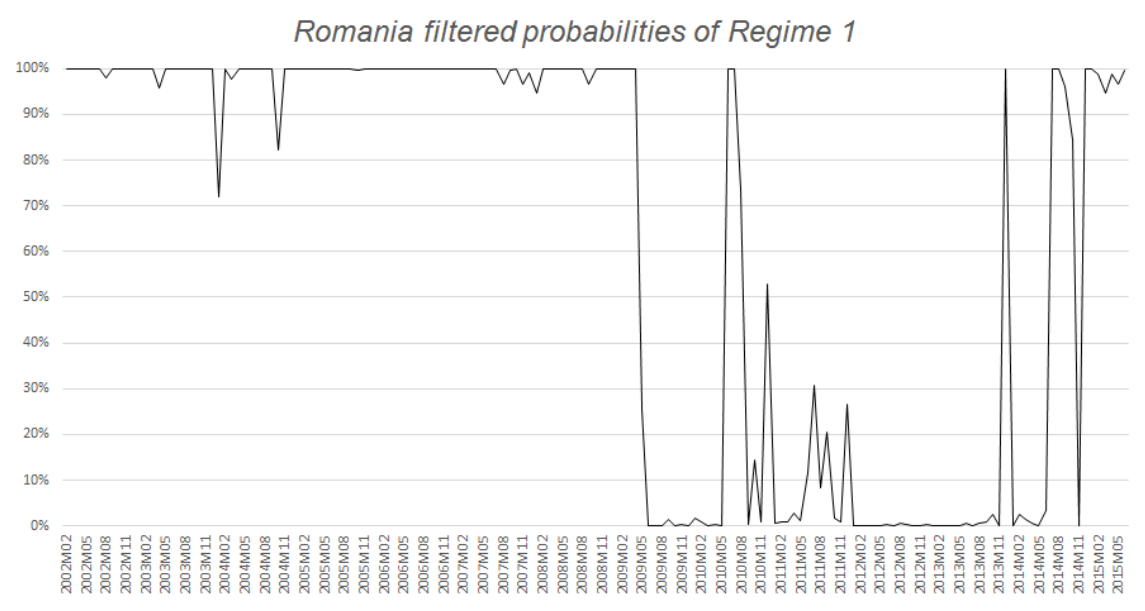


Review of Economic Analysis 10 (2018) 55-74

When we look at Figure 2, the impulse responses of credit risk to macroeconomic and bank related shocks, we observe that in both regimes credit growth (DLLOAN) has a positive but not significant impact on credit risk. Next, we look at the impact of monetary policy shock (i.e. an increase of interest rate, DIR) there is evidence of significant effect only in regime 2. In particular, at the impact, we observe an increase of credit risk, which declines after few periods and becomes negative but not-significant. This is consistent with the implication of financial accelerating mechanism that an increase on interest rate will have a negative impact on firms' balance sheets thereby decreasing the probability of repayment the value of loan and increasing the bank risk. Alternatively, higher interest rate will also increase the agency cost of lending, banks will reduce credit to high-risk firms and they will invest in more safe projects. "Flight to quality" policy will reduce bank risk. The figure also shows that the impact of industrial production growth (i.e. DIP) on credit risk is negative in both regimes but not significant.

Note in regime 2 (i.e. high volatility regime) where the response is largest there is evidence that at the impact the response is negative and significant.

When we turn to inspect the impact of the Greek banks' credit risk on the Romanian credit risk we observe that in regime 1 there are positive but marginally significant spillover effects while in regime 2 the reverse is true. Note that after the macroeconomic and financial crisis in the second half of 1990s prudent macroeconomic policies both in Bulgaria and Romania led to fast disinflation, rebounding GDP and rapidly rising profits and incomes. Duenwald et al. (2005) argue that a fall of countries' risk premia and improved business condition whetted appetite for borrowing and improved bank's perception of borrower's creditworthiness. In this setup, the perceived risk may be underestimated because the risk assessment might have reflected the prevailing benign economic conditions. At the same time, the risk monitoring might be inefficient owing to the vast amount of new loans extended at a very short period of time. Therefore, credit risk should have increased ${ }^{18}$ and was only mitigated by the set of measures taken in 2010 to mitigate the effects of the global financial crisis and the impact of Greek debt crisis on the SEE region ${ }^{19}$. In 2011 the situation in the region stabilized as significant funds were mobilized in support of banking stability.

\footnotetext{
${ }^{18}$ Duenwald et al. (2005) provide a detailed discussion concerning the risk assessment of new loans in Bulgaria and Romania during the booming period before the financial crisis in 2008 .

${ }^{19}$ More formally, the supervisory authorities in the SEE by mid 2010 begun to take measures to prevent the domestic subsidiaries from being drained dry by the parent banks in Athens.
} 


\section{KAROGLOU Impact of Credit Risk Determinants}

\subsection{Results for the Bulgarian banking system}

Figure 3 outlines the results for the determinants of the Bulgarian credit risk. The filtered probability of the low volatility regime 1 (at the top) shows that there is evidence of regime shift into the high volatility regime 2 in November 2008. We also observed that there are frequent short-lasting regime switches into high volatility regime.

Figure 2: Impulse-response graphs- Romania

Regime 1

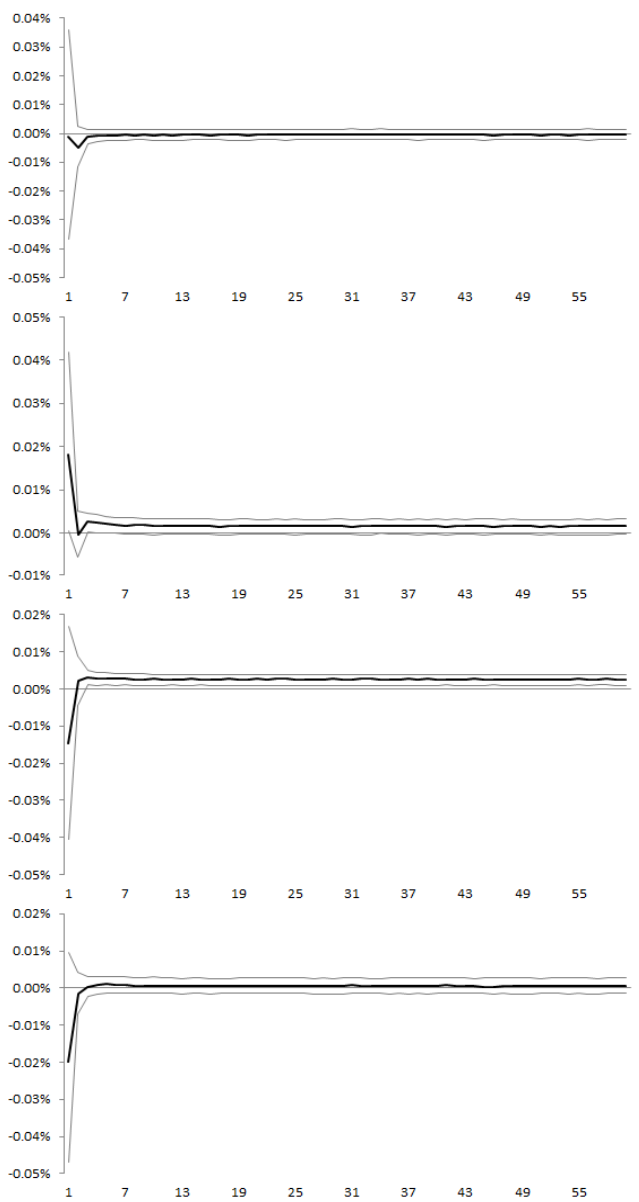

Regime 2

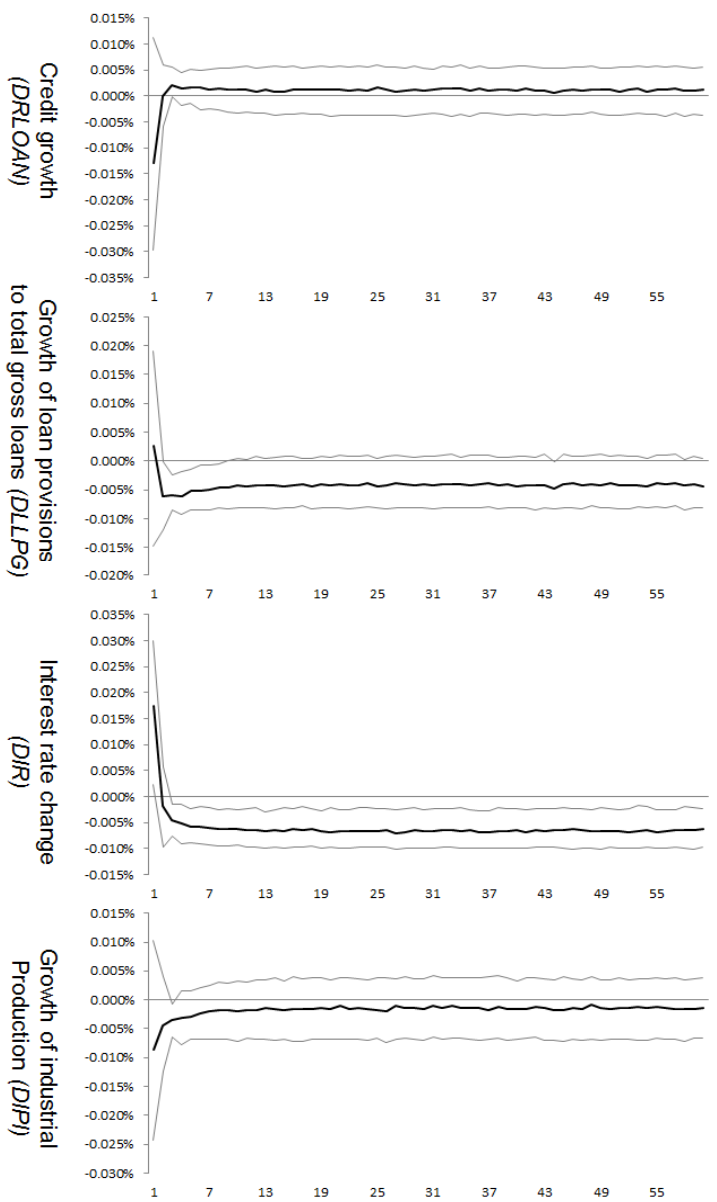

Notes: The graph depicts the results that are drawn from the MRS-SVAR with the sign restrictions identification scheme namely the responses of LLP to a shock in the variables of credit growth (DLLOAN), growth of loan provisions to total gross loans (DLLPG), interest rate changes (DIR), and growth of the industrial production index (DIP), for the first regime (left) and second regime (right). 
Review of Economic Analysis 10 (2018) 55-74

Figure 3: Filtered Probabilities for regime 1 for Bulgaria

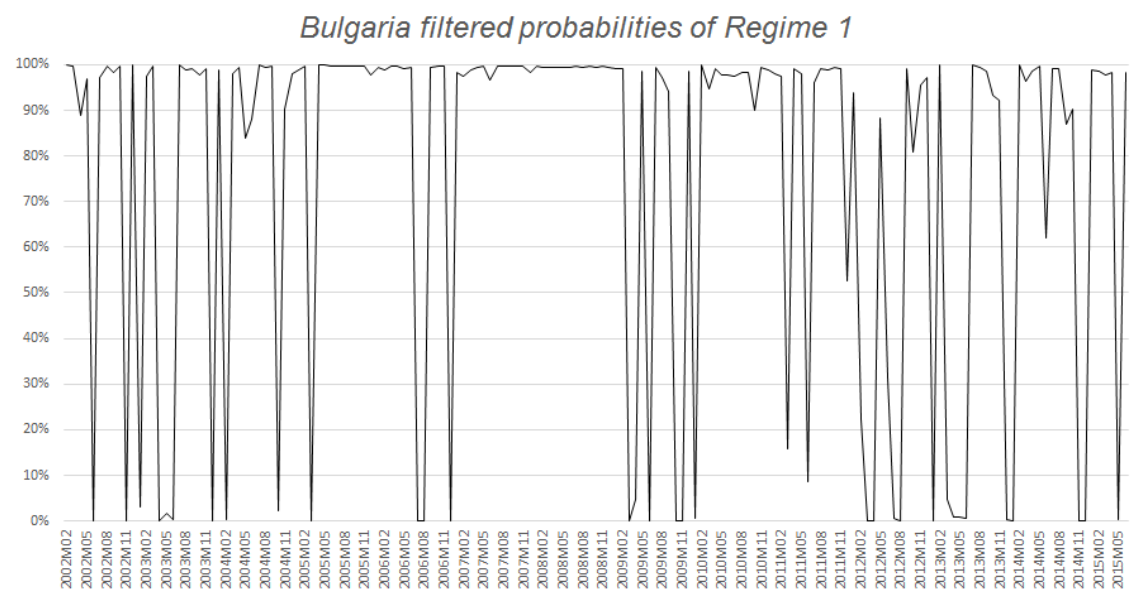

Figure 4 presents the impulse responses of the Bulgarian credit risk obtained from the MRSSVAR estimates. The main observation is that none of the variables is significant in regime 2 . The exception to this is the impact of credit growth (DLOANS), which is negative and significant the period immediately following the shock. Alternatively, in regime 1 credit growth does not have a significant effect on bank risk. Note, however, that response of bank risk in regime 1 (low volatility regime) is positive at the impact following the shock and decline after a year. This is consistent with evidence mentioned above. In particular, the adoption by the Bulgarian authorities of prudent macroeconomic policies in the second half of the 1990s has generated rose macroeconomic conditions, which in turn leads to rapid credit growth by softening bank's credit risk perception. Thus, in the low volatility regime there is an increase of credit risk while in the low volatility regime the reverse is true.

Next, we observe that there is no significant response to bank risk to monetary policy shock (DIR). More concretely, in regime 1, bank risk increases at the impact of the shock but this response is not significantly different from zero. Only three years following the shock, the response becomes negative and marginally significant. The bank risk decrease in regime 2 and remains negative for the whole period following the shock. However, the response in regime 2 is not significant even two years after the monetary policy shock occurs. These results imply that banks might flight to quality, in the sense that an increase of interest rate will increase the agency cost of lending which incentivizes banks to invest on safe assets.

When we turn to inspect the impact of the Greek banks' credit risk (DLLPG) on the Bulgarian credit risk we observe that in regime 1 there are positive and significant spillover 
Figure 4: Impulse-response graphs- Bulgaria

Regime 1

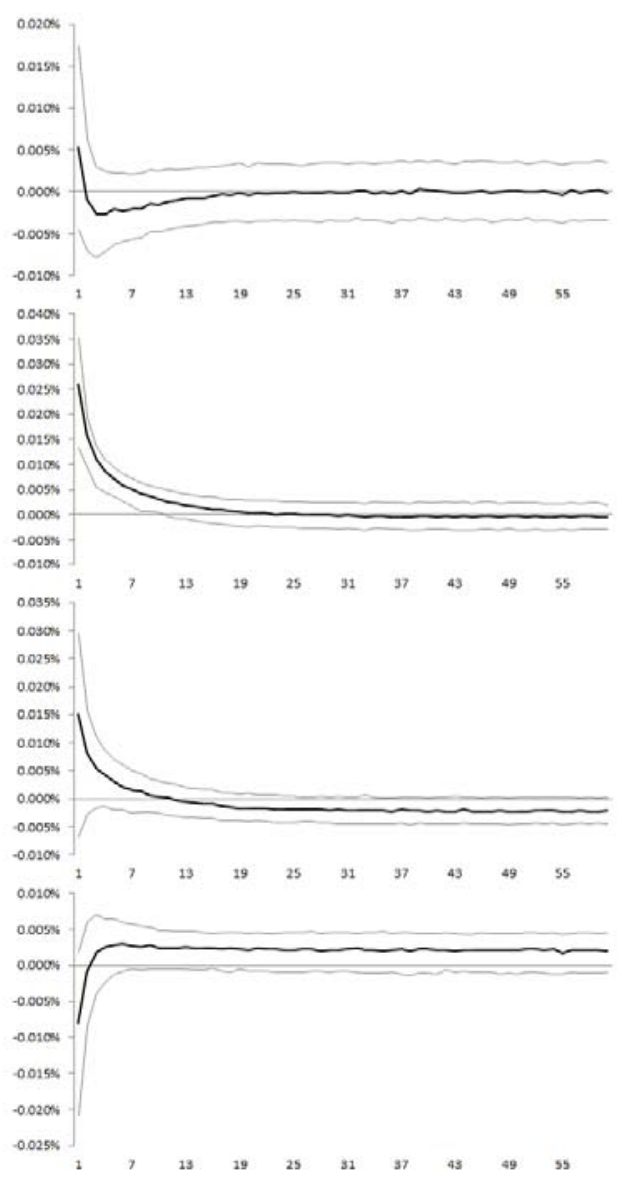

Regime 2

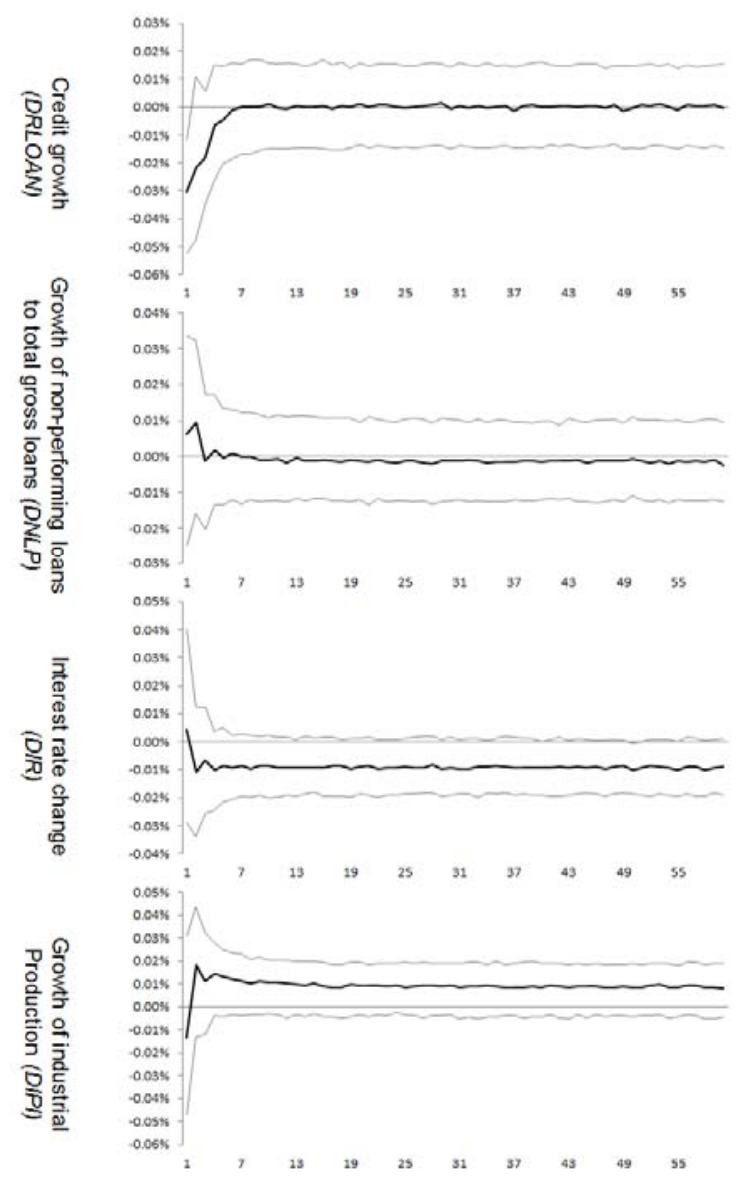

Notes: The graph depicts the results that are drawn from the MRS-SVAR with the sign restrictions identification scheme namely the responses of LLP to a shock in the variables of credit growth (DLLOAN), growth of non-performing loans to total gross loans (DNLP), interest rate changes (DIR), and growth of the industrial production index (DIP), for the first regime (left) and second regime (right).

effects. However, in regime 2 the response is negative but not significant. Similar to the Romanian case, the response of Bulgarian banks' risk to the spillover effects of Greek debt crisis is mainly explained by the prudential measures taken by the supervisory authorities along with the 'Vienna' initiative. Finally, there is limited evidence that output growth has a significant impact on banks' credit risk in the period analysed. 
Review of Economic Analysis 10 (2018) 55-74

\section{Summary and Conclusions}

The global financial crisis raises vital questions about the contribution of monetary policy to the formation of financial risk. Our study examines the impact of macroeconomic and financial variables on the credit risk of the Bulgarian and Romanian banking systems by relaxing the mainstream in the relevant literature assumption of linearity, to capture more complex and hence inevitably more realistic dynamics.

Overall, our empirical findings suggest that in both countries a positive monetary policy has a positive impact on bank risk. We underscore that a positive response of bank risk to monetary policy shock prevails only in the short run while in the medium-run banks' risk declines. This is consistent with the flight to the quality concept of Bernanke et al. (1996). In particular, the high-interest rate will increase the probability of defaults and will discourage bank managers to invest in monitoring-intensive firms and on high-risk assets. There is also strong evidence of spillover effects from the Greek credit risk to domestic bank risk in the Romanian and Bulgarian banking systems. However, this is true only for the low volatility regime (regime 1). In the high volatility regime (regime 2) only in the case of Romania, there is positive and significant response of bank risk to the shock originated by the Greek credit risk. The minimal impact of Greek spillover effects at the high volatility regime could be due to the policies imposed by the supervisory authorities of Bulgaria and Romania along with the instrumental role played by the 'Vienna' Initiative in safeguarding the financial stability of emerging Europe.

There are two main policy implications that we can draw from our findings. First, the impact of macroeconomic and financial variables on credit changes across the business cycle; thus, monetary and fiscal policy authorities should focus on reducing the volatility of key macroeconomic variables without undermining the stability of the banking system. For instance, large interest rate changes put pressure on financial markets by increasing the uncertainty within the macro-economic environment.

Second, it appears that imposing tighter regulation on credit growth may have limited the spillover effects from the Greek crisis. In terms of macroeconomic policy, it seems that the currency peg implemented in Bulgaria, which has been accompanied by budget constraints and limits to the financing of the State through the banks, may have worked well as a stabilizing factor in the banking system.

\section{References}

Alessi, L., and C. Detken (2008), Real Time Early Warning Indicators for Costly Asset Price Boom/Bust Cycles: A Role for Global Liquidity. ECB Working paper 1039.

Alfaro, R. and Drehmann, M. (2009). Macro Stress-Tests and Crises: What Can we Learn? BIS Quarterly Review.

Allen, F., and D., Gale, (2000). Bubbles and Crises. Economic Journal 110 , 236-255. 


\section{KAROGLOU Impact of Credit Risk Determinants}

Altunbas, Y., L. Gambacorta, D. Marques Ibanez, (2009) An Empirical Assessment of the RiskTaking Channel. Bank of International Settlements, mimeo.

Alves, I., (2005). Sectoral Fragility: Factors and Dynamics. BIS working paper 22.

Andreou, E., Ghysels, E. (2002). Multiple Breaks in Financial Market Volatility Dynamics. Journal of Applied Econometrics 70, 9-38.

Ang, A., and Timmermann, A. (2011) Regime Changes and Financial Markets. NBER Working paper 17182.

Angeloni, I., and E. Faia, (2009) A two Tale Policies: Prudential Regulation and Monetary Policy with Fragile Banks. Kiel Working paper 1569.

Angeloni, I., E. Faia, and M. Lo de Luca (2010) Monetary policy and Risk Taking. University of Frankfurt, mimeo.

Bernanke, B., M. Gertler and S. Gilchrist (1996) The Financial Accelerator and the Flight to Quality. The Review of Economics and Statistics 78(1), 1-15.

Bernanke, B., M. Gertler and S. Gilchrist (1999) The Financial Accelerator in Quantitative Business Cycle Framework, in J.B. Taylor and M. Woodford, eds., Handbook of Macroeconomics, North-Holland.

Blaschke W., Jones M., Majnoni G. and Peria S. M. (2001) Stress Testing of Financial Systems: An Overview of Issues, Methodologies, and FSAP Experiences. IMF Working Paper 188.

Borio, C., and H. Zhu, (2008) Capital Regulation Risk Taking and Monetary Policy: A Missing Link in the Transmission Mechanism? Bank of International Settlements, Working paper 268.

Bouvatier, V. and Lepetit, L. (2007). Banks' procyclical behavior: Does provisioning matter? International Financial Markets, Institutions and Money, Vol. 18, pp. 513-526.

Canova, F., and G., De Nicoló (2002). Monetary Disturbances Matters for Business Cycles Fluctuations in the G-7, Journal of Monetary Economics, 49, 1131-1159.

Castrén, P., Dees, S., and F. Zaher (2010). Stress-Testing Euro Area Corporate Default Probabilities Using a Global Macroeconomic Model, Journal of Financial Stability, 6. 6478.

Cooley, T., LeRoy, S. and N., Reymon (1982). Econometric Policy Evaluation: Note, American Economic Review, 74(3) , 467-470.

Cottarelli, C., G. Dell Ariccia and I. Vladkova-Hollar (2005) Early birds, late risers and sleeping beauties: Bank credit growth to the private sector in Central and Eastern Europe and in the Balkans, Journal of Banking and Finance, 29, 83-104.

Danielsson, J. (2002) The emperor has no clothes: Limits to risk modeling. Journal of Banking and Finance, $26,1273-1296$.

Davig, T., and E. M. Leeper (2007). Generalized Taylor Principle, American Economic Review, 97(3), 607-635. 
De Graeve, F., T. Kick and M. Koetter (2008). Monetary Policy and Financial (in)stability: An integrated Micro-Macro Approach. Journal of Financial Stability, 4(3) , 205-231.

Den Haan, W.J., Levin, A. (1998). Vector autoregressive covariance matrix estimation. Manuscript, University of California, San Diego.

Duenwald, C., Gueorguiev, N. and Schaechter, A. (2005). Too Much of a Good Thing? Credit Booms in Transition Economies: The Cases of Bulgaria, Romania, and Ukraine, IMF Working paper 128, 1-33.

Eickemeier, S., and B. Hofmann (2010). Housing Booms, Financial Imbalances and Monetary Policy. ECB Working Paper 1178.

Espinoza, R. and Prasad. A. (2010). Nonperforming Loans in the GCC Banking System and their Macroeconomic Effects. IMF Working Paper 224.

Frommel, M. and Karagyozova, K. (2008). Bank lending and asset prices: evidence from Bulgaria. Bulgarian National Bank Discussion paper, 65.

Gambacorta, L. (2009). Monetary Policy and the Risk-Taking Channel. BIS Quarterly Review , 43-53, Basel.

Gavin, M., and Hausmann, R. (1996). The roots of banking crises: the macroeconomic context. In Hausmann. R. and Rojas-Suárez, L. (eds.). Banking Crises in Latin America. Baltimore, Johns Hopkins Press.

Goodhart, C., and B., Hofmann, (2008). House Prices, Money, Credit and Macroeconomy. ECM Working paper 802.

Gordon, G. (2012) Some reflections on the recent financial crisis in Trade, Globalization and Development. In Sugata M. and Rajat A. (eds.) Essays in Honor of Kalyan Sanyal. Springer Verlag.

Haldane, A. G. (2009a) Why banks failed the stress test. Speech at the Marcus-Evans, Conference on Stress Testing, Bank of England, London.

Hardy, D.C. and Pazarbasioglu C. (1999) Determinants and leading indicators of banking crises: further evidence. IMF Staff Papers, 46(3), 1-12.

Hoggarth G., Logan A. and Zicchino L., 2005. Macro Stress Tests of UK Banks. BIS Papers, $22,392-408$.

International Monetary Fund (2010) Romania: Financial Sector Stability Assessment, Country Report 10/47.

International Monetary Fund (2012) Romania: Selected Issues Paper, 12/291.

Ioannidou, V., Ongena, S., and Peydro, J.L., (2009) Monetary Policy Risk-Taking and Pricing: Evidence from a Quasi-Natural Experiment. Tilburg University, Center for Economic Research,Working paper 31.

Jiménez, G. and Saurina, J. (2006) Credit Cycles, Credit Risk, and Prudential Regulation. International Journal of Central Banking, 2(2) , 65-98. 
Karoglou, M. (2010). Breaking down the non-normality of daily stock returns' European Journal of Finance, 16 (1) , 79-95.

Klein, N. (2013) Non-Performing Loans in CESEE: Determinants and Impact on Macroeconomic Performance. IMF Working Paper, 72.

Kokoszka, P., Leipus, R. (2000). Change-point estimation in ARCH models, Bernoulli 6, 1-28.

Lucas, R. Jr (1976). Econometric policy evaluation: A critique. Carnegie-Rochester Conference Series on Public Policy, Elsevier, 1(1), 19-46.

Meh, C., and Moran, K. (2010). The Role of Bank Capital in the Propagation of Shocks. Journal of Economic Dynamic and Control, 34, 555-576.

Marcucci, J. and Quagliariello, M. (2008). Credit risk and business cycle over different regimes. Bank of Italy, Working paper 670.

National Bank of Romania (2011) Financial Stability Report 2010.

Nikolaidou and Vogiatzas (2011) Investigating the determinants of nonperforming loans in the Romanian banking system: An empirical study with reference to the Greek crisis, Economics Research International, pp 1-13

Nikolaidou and Vogiazas (2014) Credit Risk Determinants for the Bulgarian Banking System, International Advances in Economic Research, Volume 20, Issue 1, pp 87-102

Nkusu, M. (2011). Nonperforming Loans and Macrofinancial Vulnerabilities in Advanced Economies. IMF Working Paper 161.

Rajan, R. (2005) Has Financial Development Made the World Riskier? NBER, Working paper 11728, Cambridge, MA.

Reinhart, C., and K., Rogoff, (2009) Is the 2007 U.S. Sub-Prime Financial Crisis so Different? An International Comparison. NBER Working paper 13761.

Sansó, A., Aragó, V. Carrion, J.L. 2003. Testing for Changes in the Unconditional Variance of Financial Time Series, Working Paper, Universitat de les illes Balears.

Shahnazarian, H., and P., Asberg-Sommer, (2009). Interdepedencies between Expected Default Frequency and the Macroeconomy. International Journal of Central Banking , 5, 83-110.

Sorge, M. (2004). Stress-testing Financial Systems: An Overview of Current Methodologies, BIS Working Paper 165.

Zhang, L. (2009) Bank Capital Regulation, the Lending Channel, and the Business Cycles. Deutsche Bundesbank, Working paper 33/2009. 
Review of Economic Analysis 10 (2018) 55-74

\section{Appendix: The Dataset}

Table 1: The dataset and the sources used

\begin{tabular}{|c|c|c|}
\hline Variables & Definition - Interpretation & Source \\
\hline $\begin{array}{l}\text { Non-performing loans to total } \\
\text { loans (NPL) }\end{array}$ & $\begin{array}{l}\text { Doubtful and loss loans to total gross } \\
\text { loans granted by Bulgarian banks }\end{array}$ & Bulgarian National Bank (BNB). \\
\hline $\begin{array}{l}\text { Loss Loan Provisions to total } \\
\text { loans (LLP) }\end{array}$ & $\begin{array}{l}\text { Doubtful and loss loans provisions to } \\
\text { total gross loans granted by Romanian } \\
\text { banks }\end{array}$ & $\begin{array}{l}\text { National Bank of Romania } \\
\text { (NBR). }\end{array}$ \\
\hline $\begin{array}{l}\text { Loss Loan Provisions to total } \\
\text { loans (LLP) }\end{array}$ & $\begin{array}{l}\text { Loss loans provisions to total gross } \\
\text { loans - domestic and foreign - } \\
\text { granted by Greek banks }\end{array}$ & Bank of Greece. \\
\hline Credit growth (LLOAN) & $\begin{array}{l}\text { Growth rate }(\% \text { p.a. }) \text { of gross loans } \\
\text { granted by Bulgarian-Romanian } \\
\text { banks to households and non- } \\
\text { financial corporations. }\end{array}$ & BNB \& NBR. \\
\hline Industrial Production (IP) & $\begin{array}{l}\text { Percentage change in index of } \\
\text { industrial production, over previous } \\
\text { year. }\end{array}$ & $\begin{array}{l}\text { National Statistical Institute } \\
\text { (Bulgaria), National Institute of } \\
\text { Statistics (Romania). }\end{array}$ \\
\hline Money Market Rate (IR) & $\begin{array}{l}\text { Weighted average rate on interbank } \\
\text { loans (Bulgaria). } \\
\text { 91-days Treasury bills (Romania). }\end{array}$ & $\begin{array}{l}\text { IMF, International Financial } \\
\text { Statistics. }\end{array}$ \\
\hline
\end{tabular}

